\title{
Costs and benefits of early response in the COVID-19 outbreak in Cameroon: DALYs, treatment cost and labour supply lost.
}

\author{
Kinga Bertila Mayin ${ }^{1,3}$, Promise Aseh Munteh ${ }^{1}$ and Mbacham Fon Wilfred ${ }^{2 *}$ \\ ${ }^{1}$ Department of Health Economics and Policy Management, Faculty of Business and Management \\ Sciences, Catholic University of Cameroon (CATUC) Bamenda. \\ ${ }^{2}$ The Biotechnology Centre, University of Yaounde \\ 3 Department of economic, Faculty of economic and management, The University of Bamenda \\ Email:bertsking@yahoo.com, aseh.promise@,catuc.org, wfmbacham@yahoo.com
}

\begin{abstract}
COVID-19 has had multiple effects on our daily lives and led to a general recession of what is today known as the Coronavirus recession. This is an economic recession across the world economy in 2020 due to the 2019/20 coronavirus pandemic (Schwarts, 2020). The trajectory of COVID-19 is highly uncertain. Variables include how long it will take for the virus to play out, how many people will be infected, how many will die, and whether the virus will spread significantly ( $\underline{\text { Zandi }}$ et al, 2020). There is thus a need for studies to analyze the detail cost and benefit of an early response to this pandemic. This work sets out to calculate the costs and benefits of early response in the COVID-19 outbreak in Cameroon using DALYs, healthcare expenditure and labour supply lost. In order to do this, secondary data was collected from the Ministry of Public Health periodic reports on the COVID-19 situation and from the global disease burden report published in 2015.

Data were analyzed using standard formula as used in Shutterstock, (2020) to calculate DALY, while percentages, algebra and other descriptive statistical tools like charts were used to present findings. Results showed that Cameroon had 658, 2265, 7599 and 14,916 cases one, two, three and months respectively after the outbreak.

Results further show a 16.37 loss years of "healthy" life per person and a total of 10771.46DALYs, 37078.05DALYs, 124,395.6DALYs and 244,174.9DALYs after one, two, three and four months of onset. Health care expenditure for all patients stood at 2.632M, 9.060M, 30,396M and 59,664M FCFA for one, two, three and four months respectively after onset COVID 196 of March 2020. Lastly, all patients in total lost 105,280, 362,400, 1215840 and 2386560 hours of labour one, two, three and four months respectively after the onset of COVID 19 in Cameroon.

This study thus concludes that COVID-19 has enormous cost to patients and government and a timely intervention will lead to great benefits. It recommends strict adherence to government's preventive measures modified from the WHO guide. This will lessen the economic consequences of COVID 19 in Cameroon thus preventing the Economy from sinking into a recession.
\end{abstract}

Key words : Covid-19, Cost, benefit and Intervention, Cameroon, DALY, economic, Recession

Received: 20/05/2020

Accepted: 16/07/2020

DOI: https//dx.doi.org/10.4314/jcas.v16i1.4

(C) The Author. This work is licensed under the Creative Commons Attribution 4.0 International Licence. 


\section{Resumé}

Le COVID-19 a eu de multiples effets sur notre vie quotidienne et une récession générale de ce que l'on appelle aujourd'hui la récession du coronavirus. Il s'agit d'une récession économique dans l'économie mondiale en 2020 en raison de la pandémie de coronavirus 2019/20 (Schwartz, 2020). La trajectoire du COVID-19 est très incertaine. Les variables incluent le temps qu'il faudra au virus pour se manifester, le nombre de personnes infectées, le nombre de personnes qui mourront et si le virus se propagera de manière significative (Zandi et al, 2020). Il est donc nécessaire de mener des études pour analyser en détail les coûts et les avantages d'une réponse précoce à cette pandémie. Ce travail vise à calculer les coûts et les avantages d'une réponse précoce à l'épidémie de COVID-19 au Cameroun en utilisant les DALY, les dépenses de santé et l'offre de main-d'œuvre perdue. Pour ce faire, des données secondaires ont été collectées à partir des rapports périodiques du Ministère de la Santé publique sur la situation du COVID-19 et du rapport mondial sur la charge de morbidité publié en 2015.

Les données ont été analysées à l'aide de la formule standard utilisée dans Shutterstock, (2020), pour calculer DALY, tandis que les pourcentages, l'algèbre et d'autres outils statistiques descriptifs comme les graphiques ont été utilisés pour présenter les résultats. Les résultats ont montré que le Cameroun comptait 658, 2265, 7599 et 14916 cas respectivement un, deux, trois et mois après l'épidémie.

Les résultats montrent en outre une perte de 16,37 années de vie «saine» par personne et un total de 10 771,46 DALY, 37078,05 DALY, 124 395,6 DALY et 244 174,9 DALY après un, deux, trois et quatre mois d'apparition. Les dépenses de santé pour l'ensemble des patients se sont élevées à 2,632 M, 9,060 M, 30396 M et 59664 M FCFA pour respectivement un, deux, trois et quatre mois après le début du covid le 6 mars 2020. Enfin, tous les patients ont perdu au total 105 280, 362 400, 1215840 et 2386560 heures de travail un, deux, trois et quatre mois après. Cette étude conclut donc que le COVID-19 a un coût énorme pour les patients et le gouvernement et qu'une intervention opportune entraînera de grands avantages. Il recommande le strict respect des mesures préventives du gouvernement modifiées par rapport au guide de l'OMS. Cela atténuera les conséquences économiques du covid au Cameroun, empêchant ainsi l'économie de sombrer dans une récession.

Mots clés: Covid-19, Coût, bénéfice et intervention, Cameroun, DALY, économique, Récession 


\section{Introduction}

On the 12 January 2020, the World Health Organization (WHO) confirmed that a novel coronavirus (later termed SARS CoV-2 and the disease it causes COVID-19) was the cause of a respiratory illness in a cluster of people in Wuhan City, Hubei Province, China, which was reported to the WHO on $31^{\text {st }}$ December 2019. After emerging in Wuhan, China the coronavirus has spread to at least 169 countries and regions. The World Health Organization thus declared the outbreak a pandemic (Anadolu Agency report, 2020). This pandemic has led to enormous medical consequence and a general recession of what is today known as the Coronavirus recession which refers to an economic recession across the world economy in 2020 due to the 2019/20 coronavirus pandemic (Schwarts, 2020). The trajectory of COVID-19 is highly uncertain. Variables include how long it will take for the virus to play out, how many people will be infected, how many will die, and whether the virus will spread in a significant (Zandi et al, 2020). Some economists have suggested that China's economy may contract for the first time since the 1970s. Caixin's purchasing managers index for the services sector of China's economy fell to 26.5 in February 2020, the lowest figure recorded since the survey's advent in 2005 (Laura, 2020). The great economic consequence of corona has been extended by the loss of jobs and hours labour supply on the part of the patients due to disability and nonpatients due to lockdowns and recession of the Economy. In January and February 2020, during the height of the epidemic in Wuhan, about 5 million people in China lost their jobs. In March 2020, more than 10 million Americans lost their jobs and applied for government aid (Americans Filed for Unemployment, 2020). According to official statistics, the deadly contagious disease had infected roughly 5,300 persons across 47 African nations as of March 31, 2020. According to a study entitled, Tackling COVID-19 in Africa (2020), by global auditing firm McKinsey \& Company's experts, Africa's economies could experience a loss of between $\$ 90$ billion and $\$ 200$ billion USD in 2020. They noted that these losses will stem mostly from cuts in private spending and widespread travel bans in Africa, as well as supply-chain disruptions, lowered demand for the continent's non-oil exports, and delays or cancelations of foreign investments caused by the ongoing epidemic, the report argued that roughly 15\% were due to "oil-price effects." (Anadolu, 2020).

The 2019/20 coronavirus pandemic was confirmed to have spread to Cameroon, Central Africa on 6 March with its first confirmed case The total number of COVID-19 cases kept climbing up in the country and on the 24 of March 2020 Cameroon confirmed its 1st death from COVID-19. On 27 March, the total number of COVID-19 cases in Cameroon reached 91.This was therefore signs that COVID-19 is real and deadly thus requiring urgent intervention measures to treat and curb its spread in Cameroon so as to avert the serious medical and Economic consequences on such economy whose medical facilities and economic strength cannot match the developed countries which had registered thousands of deaths. Dr. Nyuki Fonyuy, National President and Dr. Thierry Fozing, Chairman of the COVID-19 Commission in their reports after reviewing the main epidemiological approaches (Dutch model, Korean/German model, Raoult model) currently in use around the world to deal with the COVID-19 pandemic recommended a proper solution for Cameroon. According to this report, the solution in Cameroon must be unique to avoid major economic consequences considering the fact that the informal sector constitutes $70-80 \%$ of jobs and $38 \%$ of the population still lives below the poverty line; Most people earn their living on a daily basis and have no savings; shortage of drinking water,electricity to preserve food; incivility; the national economy is facing a serious liquidity crisis, exacerbated by the conflicts in the English-speaking area and in the Far North and that the Cameroonian health system is in agony. A number of measures were thus put in place with the most important being the mobilization of funds to support the rise in 
medical expenditures, closure of Cameroon's land, air and sea borders, test campaign to curb the spread and economic consequence of covid 19. On 10 April 2020, the government took 7 additional measures to stop the spread of COVID-19 in Cameroon.

Despite the measures put in place in March, April and May, The COVID-19 pandemic continues to worsen around the world and furthermore in Cameroon. Since 1 May the number of cases has increased four-fold from 1,832 cases and since 21 May it has doubled from 4,288 cases. As of 10 June 2020, there have been over 8,681 confirmed COVID-19 cases, with 208 deaths (UNICEF, 2020). Cases were reported in all ten regions of the country though the majority remains in Central and Littoral regions. (Africanews, 2020). On the 30 of April, the Government relaxed several key preventive measures and by June 1st reopened schools (CHA, 2020). In April- May, an analysis of the socio-economic impacts of the epidemic was carried out under UNDP leadership. According to the results of the analysis, overall, $82.6 \%$ of business leaders reported experiencing a drop-in production. However, the situation was more pronounced in formal sector enterprises than in the informal sector. In terms of impact, almost half of the negatively affected companies said they have recorded a drop of more than $50 \%$ in their production.

Looking at the above interventions on Coronavirus, carried out in Cameroon by both health and state personnels, the strong fear is that other health interventions might be neglected if researches toward estimating the real burden of such diseases compare to other diseases in Cameroon are not carried out. Such research should be tailored towards investigating the exact cost of the disease in Cameroon compared to other diseases in a figure that can be used globally to compare the effect of these diseases. Studies in other countries have investigated the effects of the outbreak in different intervention scenarios but little work has been performed on the combination of potential health benefits and cost savings of earlier interventions. In this paper, we focus on providing estimates of costs and health consequences of the outbreak and the potential benefits of an earlier response. To enable comparability, we measure health losses in Disability Adjusted Life Years (DALY) and take into account the costs associated with an outbreak both within_(health cost) and outside (labour supply) the healthcare sector.

\section{Literature Review}

Very few works have been written on the economic consequences of COVID-19 especially in terms of DALY and labor supply lost. To gain a relative understanding of the magnitude of the impact of COVID-19 it is necessary to look at the impact on Disability Adjusted Life Years (DALY) carried out in other studies. Amongst these rare studies is the work of Shutterstock, (2020) who found out that child and maternal malnutrition, and its resultant myriad of short and long term health problems, is by far the leading cause of lost DALYs in India at 83 million annually, and he assumed this will be exacerbated significantly by the hardships imposed by a lockdown strategy. In comparison, he predicted that COVID-19 will cause the loss of 17 million DALYs, if every person who dies loses an average of 7.5 DALYs, given that deaths with COVID19 tend to occur in the elderly and those with underlying illnesses. He concluded that in India, and in the United States of America, more children will die from suppression, mitigation, lockdowns and the economic downturn than from COVID-19 (Shutterstock, 2020).

According to Abramowicz (2020) Media Contact

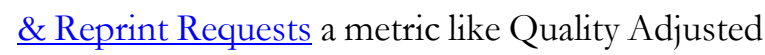
Life Years (QALYs) could be used to aggregate 
the burden of COVID-19. To him, in assessing public policy interventions, such as closing schools and limiting travel, it is necessary to at least informally perform some sort of cost-benefit analysis, assessing the economic cost of an intervention and comparing it with the benefit in reduced deaths and illness. He specified that the calculation of DALYs than QALYs will be most appropriate. According to him, QALYs unlike DALYs does not seem to enter into discussions of COVID-19 due to the following explanations:(1) Too many unknowns: including how many people carry the virus with mild symptoms or asymptomatically. It is difficult to construct a baseline case of how many people might become infected and die with the absent government intervention, so any cost-benefit analysis would largely be guesswork. (2) Real option theory: a more sophisticated version of the previous hypothesis is that a cost-benefit analysis might be too simplistic and in particular might understate the value of extraordinary efforts to contain the virus while we develop better information about its dangers. (3) Lost QALYs: Discussion of QALYs almost always focuses on QALYs saved by interventions. There are exceptions, such as this one measuring the global burden of disease with the related measure of DALYs. (4) Not medical treatments. Typically, QALYs are used to measure life-years saved by new medical treatments. Here, the question is the expected QALY savings from quarantines, canceling sporting events, and the like. (5) Prospect theory: The value of a QALY may differ based on whether we focus on a QALY saved or a QALY lost. "Because the baseline is the preCOVID-19 world, whether we are focusing on the burden of disease or the effectiveness of interventions, we frame the new suffering as losses rather than gains thus making DALYs a better estimation" (Abramowicz, 2020). According to Fonyuy and Fozing report 2020, a stay in an intensive care unit costs at least 300,000 FCFA per day in Cameroon with Hydroxychloroquine +Azithromycin (total cost 13EUR per patient in France for the whole duration of the treatment).

\section{Model: Transmission model}

To explore the potential benefits of earlier response we used information at the various levels of the transition model specified in Kellerborg (2020). The model aims at describing the natural course of the disease and incorporating certain specific context such as hospitalization in either holding centers or treatment centers. Figure 1 below depicts the model schematics: upon contracting the virus the individual leaves the Susceptible compartment (S) and enters the latent compartment (E). From the E compartment the individuals' transition to the infectious compartment (I) as illustrated on the figure. The whole population is assumed to be susceptible.

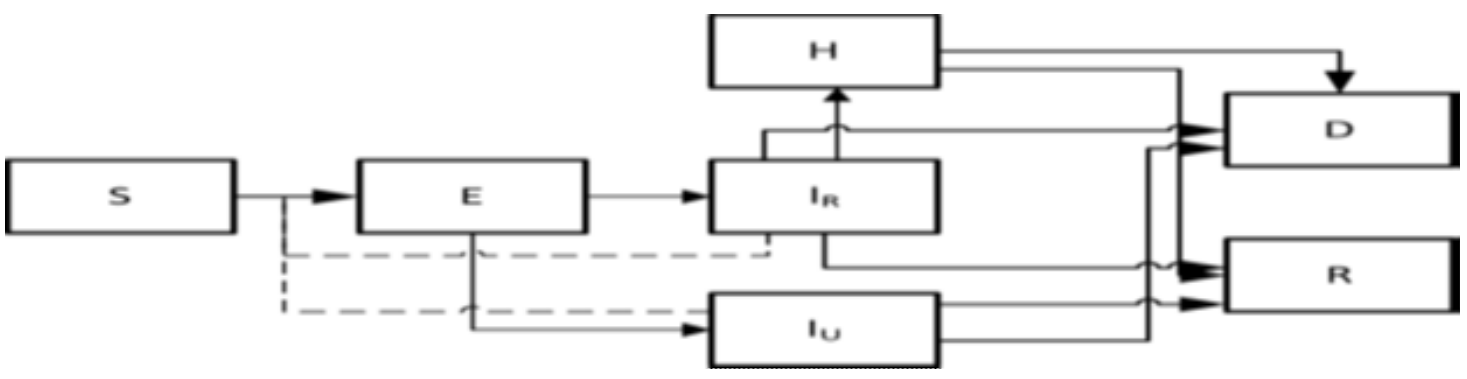

Fig. 1 Compartment model schematic. Solid lines indicate transition paths; dashed lines indicate transmission routes. With the following compartments, Susceptible (S), Exposed (E), Infectious and reported (IR), Infectious and not reported (IU), Hospitalized (H), Dead (D) and lastly Recovered (R). source Kellerborg (2020). Due to the fact that it was difficult to get data on the number of people who enter and leave each of these compartments, we concentrated on compartments like the infectious, reported death and recovery where official data was available in our analyses. 


\section{Methodology}

The health cost lost to COVID-19 in this work is expressed in terms of DALYs, health care expenditures and hours of labour supply lost. To estimate health losses we attached disability weights from the Global Burden of Disease (GBD) 2015 study to the relevant compartments in our model. DALYs represents the total number of years lost to illness, disability, or premature death within a given population. DALYs are calculated by adding the number of years of life lost to the number of years lived with disability (YLDs) for a certain disease or disorder (Murray, 2010). Thus, DALY is expressed as DALY = YLM + YLD and one DALY = one lost year of "healthy" life. To get the disability index, this study made use of data from the work of Joshua et al. (2015) on the Disability weights for the Global Burden of Disease 2013 published in Lancet Glob Health (2015). Data on the number of cases and death in Cameroon was obtained from the Ministry of Public Health periodic report (Cameroun: Rapport de situation COVID-19). Data on the cost and time spent on COVID-19 treatment was gotten from the report of Dr.Nyuki Fonyuy, National President and Dr. Thierry Fozing, Chairman of the COVID-19 Commission.

Other findings from the field on the health care expenditures were presented with frequencies, percentages, algebra and charts.

\section{Results}

One month after the first case of COVID-19 was detected in Cameroon, the active cases stood at 658 with 9 deaths and 17 recoveries. Two months after, the active cases rose to 2,265 active cases with 108 deaths and 934 recoveries. Three months after the active case stood at 7599 cases with 212 deaths and four months after on the 7 of July, the figures stood at 14,916, with 359 death and 11525 recoveries. This gives a percentage increase of $244.22 \%$ in the number of cases, $1100 \%$ in the number of death and $5394.12 \%$ increase in the number of recoveries. Four months after, the number of cases had increased by $558 \%, 232 \%$ and $1134 \%$ increase in recovery as seen on figure 2. This result has one interesting implication. Though the number of cases of death has increased, the recovery rate too has increase sharply far more than the increase in cases and death. This thus implies that the curatives measures aimed at curbing the effect of covid 19 in Cameroon is far more effectively than the preventive strategies.

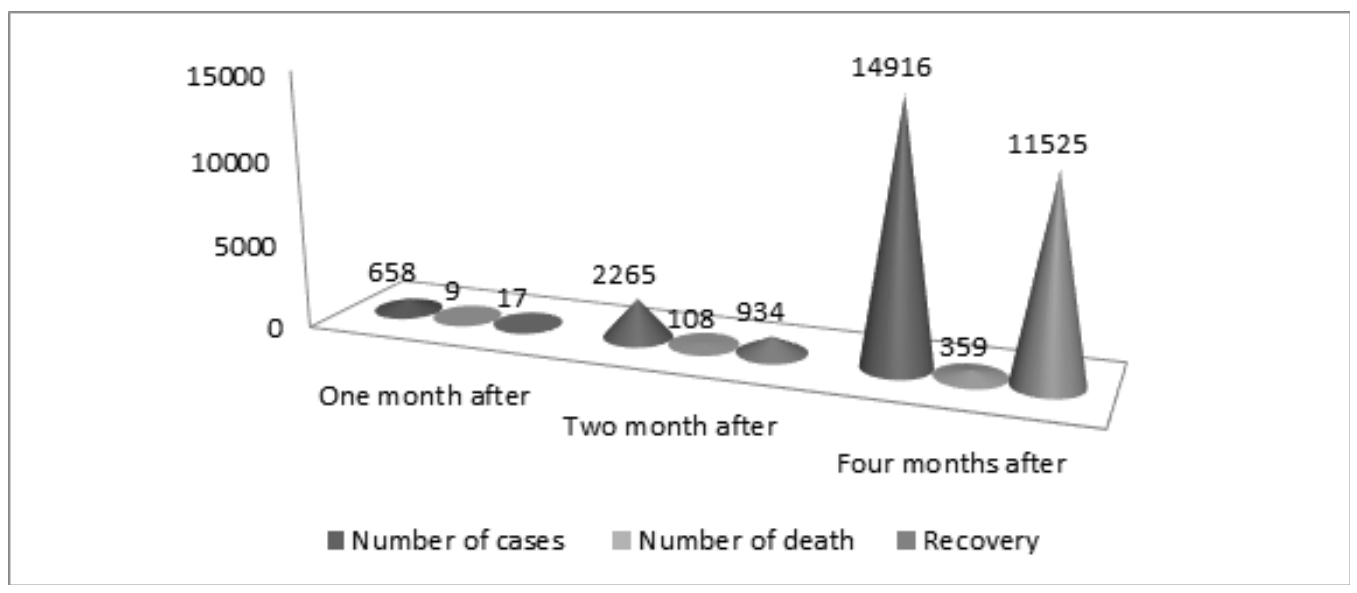

Figure 2; Cases of covid-19 one, two and four months after first case detection 
The mean age at death for COVID-19 was calculated to be 42.12 . Life expectancy for Cameroon in 2016 report for global health observatory was 57 for male and 59 for women giving an average of 58. Approximately COVID19 patient lives one month in disability giving 0.08 year spend in disability.

DALYs $=$ Number of years of life lost $($ YLM $)+$ Number of years lived with disability (YLDs). Where $=$ Number of years of life lost $(Y L L)=$ life expectancy - mean age at death while the Number of years lived with disability (YLDs) $=$ disability index + year in disability

$\mathrm{DALY}=58-42.12+0.08+0.408$ this gives $15.88+0.49=16.37 \mathrm{DALY}$ per person

This result represents 16.37 lost years of "healthy" life. The total number of years lost by all cases on the 6 of April was 10771.46 (16.37* 658) DALY while that of 6 of May was 37078.05 $(16.37 * 2$ 265) DALYs. For 6 June 124,395.6 $(16.37 * 7599)$ and 7 July $244,174.9(16.37 *$ $14,916)$. This means that on the $6^{\text {th }}$ of April 2020, which is exactly one month after the onset of COVID-19 in Cameroon, the COVID-19 patients put together lost 10,771.46FCFA per healthy year of life. These figures got worse two months after with the loss of 37078.05 years of healthy life for all COVID-19 patients as of the 6 of May 2020. Three and four months later, that DALY lost figures stood at 124,395.6 and 244,174.9 respectively. Thus, timely intervention would have adverted 244,174.9FCFA per year of healthy life lost.

The cost of COVID-19 to the government was estimated on the cost of healthcare expenditures. Health care expenditure for one patient according to official report from the Ministry of Public Health is $4,000,000 F C F A$. Thus total for all the patients was $2,632 \mathrm{M},(4 \mathrm{M} * 658)$ a month after and $9,060 \mathrm{M}(4 \mathrm{M} * 2265)$ on the 6 of May which is two months later. For June and July, the figures stood at 30,396M_(4M*7599) and 59,664M (4M $* 14,916)$ respectively.
Thirdly, the lost that would have been adverted in a timely intervention of COVID-19 can be measured in terms of hours of labour lost. The patients lost 40 hours per week and for the approximately 1 month of sickness they lost 105,280 (40hours*4weeks* 658hours in a week) hours of labour and two months $(6 / 05 / 2020)$ patients lost $362,400(40 * 4 * 2265)$ hours of labour. Three months and four months after patients lost $1215840 \quad(40 * 4 * 7599)$ and 2386560 $(40 * 4 * 14,916)$ respectively.

\section{Conclusion}

This work set out to calculate the costs and benefits of early response in the COVID-19 outbreak in Cameroon using DALYs, treatment cost and labour supply lost. In order to do this, secondary data was collected from the Ministry of Public Health periodic reports on the COVID19 situations and from the global disease burden report published in 2015. Results showed that Cameroon had 658, 2265, 7599 and 14,916 cases one, two, three and months respectively after the outbreak. Results further show a 16.37 lost years of "healthy" life lost per person and a total of 10771.46DALY , 37078.05DALYs, 124,395.6 DALYs and 244,174.9 DALYs after one, two, three and four months of onset. Health care expenditure for all the patients stood at $2.632 \mathrm{M}$ $9.060 \mathrm{M}, 30,396 \mathrm{M}$ and $59,664 \mathrm{M}$ for one, two, three and four months respectively after onset on the 6 of May 2020. Lastly, all patients in total lost 105,280, 362,400, 1215840 and 2386560 hours of labour one, two, three and four months after. This study thus concludes that COVID-19 has enormous cost to patients and government and a timely intervention will lead to great benefits that will advert a recession in Cameroon. It recommends strict adherence to the WHO and the government's preventive measures to make Cameroon a COVID-19 free country. 


\section{References}

Africanews (2020) Cameroon streets crowded despite COVID-19. https://

www.africanews.com/2020/03/21/cameroonstreets-crowded-despite-covid-19//. Cameroon (2016). Global health observatory report. https://www.who.int/countries/cmr/ en/

Cameroon COVID-19 (2020). Mobility restrictions. https://dtm.iom.int/reports/ cameroon- $\% \mathrm{E} 2 \% 80 \% 94$-covid- 19 $\%$ E2\%80\%94-mobility-restrictions-may-2020 Cameroon(2020). COVID-19 Rapport de Situation No33_05 au 07 June 2020. https:// www.humanitarianresponse.info/en/ op $\%$ C $3 \%$ A 9 rations/cameroon/document/ cameroon-covid-19-rapport-de-situationn\%C2\%B03305-au-07-juin-2020.

Cameroon(2020). North-West and South-West, Health Cluster Update, 13 -24 APRIL, 2020. https://reliefweb.int/report/cameroon/ cameroon-north-west-and-south-west-healthcluster-update-13-19-may-2020-bulletin-04 Cameroun (2020). Période du 04 au 07/04/2020 Rapport de situation COVID-19 no 15. https:/ / reliefweb.int/report/cameroon/camerounrapport-de-situation-covid-19-n-19-p-riode-du17-au-19042020.

Cameroun(2020) Période du 05 au 08/05/2020 Rapport de situation COVID-19 no 25. https:// www.humanitarianresponse.info/en/ op \%C3\%A9rations/cameroon/document/ cameroon-covid-19-rapport-de-situationn\%C2\%B02505-08-mai-2020.

Cameroun, Cameroon PM (2020). Covid19Cmr CR de la réunion du Comité Interministériel de suivi-évaluation Covid19. https:// mobile.twitter.com/CameroonPm237/status/ 1253355564769447938

CNBC (2020). Roughly 5 million people in China lost their jobs in the first 2 months of 2020. https://www.teletrade.eu/analytics/news / 3624092
CRTVweb (2020). "7 mesures supplémentaires contre la propagation du Covid19 au Cameroun Mesure1 : port du masque obligatoire". https:// mobile.twitter.com/CRTV_web/status/ 1248370100622757888.

JeuneAfrique (2020). Coronavirus au Cameroun : les opérations de solidaritédans le viseur du gouvernement. JeuneAfrique.com. https:// www.jeuneafrique.com/925306/politique/ coronavirus-au-cameroun-les-operations-desolidarite-dans-le-viseur-du-gouvernement/. JeuneAfrique (2020). Coronavirus au Cameroun : Paul Biyaannonce la libération de certainsprisonniers - JeuneAfrique.com" https:/ /www.jeuneafrique.com/928525/politique/ coronavirus-au-cameroun-paul-biya-annonce-laliberation-de-certains-prisonniers/

Journal du Cameroun.com (2020). Cameroon's Coronavirus cases move up to 142".. 30 March 2020. https://www.journalducameroun.com/en/ cameroons-coronavirus-cases-move-up-to-142/. KlasKellerborg, Werner Brouwer and Pieter van Baal (2020). Costs and benefits of early response in the Ebola virus disease outbreak in Sierra Leone Cost EffResourAlloc (2020) 18:13.https:// doi.org/10.1186/s12962-020-00207-x

Kouagheu Josiane (2020). Cameroon confirms first case of coronavirus". Reuters.

Laura He, CNN Business (2020). China's economy could shrink for the first time in decades because of the coronavirus. https://edition.cnn.com/ $2020 / 03 / 04 /$ economy/china-servicesemployment-coronavirus/index.html.

Lukong, Pius Woussou Kossi (2020). “Cameroon, Togo Report First Confirmed Cases of Coronavirus". Bloomberg.

Mark Zandi, Cristiande Ritis, Ryan Sweet, Steven Cochrane, Katrina Ell (2020) Anadolu Agency report

Michael Abramowicz (2020). Covid-19 and Qalys. Archivesvolokh.Com. https://reason.com/2020/ 03/05/covid-19-and-qalys/ 
Ministry of Public Health (2020). Cameroon: Covid-19 situation as of 06 may 2020 Figures. https://reliefweb.int/report/cameroon/ cameroon-covid-19-situation-06-may-2020

Murray Christopher J L, Joshua A Salomon, Juanita A Haagsma, Adrian Davis, Charline Maertens de Noordhout, Suzanne Polinder, Arie H Havelaar, Alessandro Cassini, Brecht Devleesschauwer, Mirjam Kretzschmar, Niko Speybroeck, , Theo Vos. (2015) Disability weights for the Global Burden of Disease 2013 Study. Lancet Glob Health 2015;3: e712-23

Novel Coronavirus Disease (Covid-19) (2019) China Covid-19 figures sourced from: The Novel Coronavirus Pneumonia Emergency Response Epidemiology Team, 'The Epidemiological Characteristics of an Outbreak of 2019 - China, 2020', in China CDC Weekly/ Vol 2/ No. 8, pp. 113-122

OCHA (2020). Cameroon COVID 19 Emergency Situation Report No. 02 - As of 1st June 2020. https://reliefweb.int/report/cameroon/ cameroon-covid-19-emergency-situation-reportno-02-1 st-june-2020.

PopulationPyramid (2019). Population figures. https://www.populationpyramid.net/world/ 2019/

Reynolds, Matt (2020). What is coronavirus and how close is it to becoming a pandemic? https://

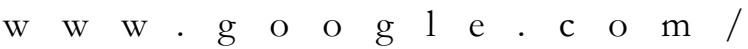

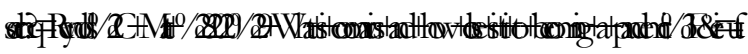
$8 \&$ oe $=u t f-8 \& a q=t \& r l s=$ org. mozilla:enGB:official\&client $=$ firefox-a\&channel $=$ fflb

Schwarty, Nelson D. (2020). "Coronavirus Recession Looms, Its Course 'Unrecognizable". The New York Times. https://www.nytimes.com/ 2020/03/21/business/economy/coronavirusrecession.html.

Slate (2020). Americans Filed for Unemployment Last Week. https://slate.com/business/2020/ 04/unemployment-jobs-numbers-economycoronavirus.html.
UNESCO (2020). COVID-19 Educational Disruption and Response. https:/ / en.unesco.org/ news/covid-19-educational-disruption-andresponse.

UNHCR (2020). Covid-19 response: West and central Africa o6 April 2020. www.unhcr.org 1 UNICEF (2020)Cameroon: COVID-19 Situation Report \#12 (May 29 - 12 June 2020). https:// reliefweb.int/report/cameroon/cameroon-covid19-situation-report-12-may-29-12-june-2020. WHO (2020). Coronavirus disease 2019 (COVID19) Situation Report - 81" https://www.who.int/ fr/emergencies/diseases/novel-coronavirus2019. 